\title{
Travelling police: the potential for change in the wake of police reform in West Africa
}

\begin{abstract}
Police models travel around the globe and many arrive in the shape of police reforms in West Africa. On the ground, these transnational connections are composed of interactions between police officers carrying and re ceiving such models. Similar to the travel of other models, African officers usually adapt and subvert official reforms. In this article, we argue that the potential for wide ranging organisational change is caused not so much by these reform programmes, but rather emerges from the encounters that such travels bring along. In these encounters, officers tell stories that challenge or stabilise notions of police work for those involved.
\end{abstract}

Key words transnational, policing, travelling models, narrative, West Africa

\section{Introduction}

Police organisations in West Africa are deeply interconnected with other police organisations worldwide. European, US and Chinese liaison officers organise training courses, West African police organisations work with them in joint operations against transnational terrorism and drug trafficking, and every year hundreds of West African police officers take part in United Nations Police peacekeeping missions. This is all part of what Alice Hills calls the 'international police-reform industry' (2008: 220; see also Goldsmith and Sheptycki 2007) and while a lot of research has been done in its service, hardly any research takes this industry as an object of study. The relations between police organisations in West Africa and elsewhere have three dimensions: a logistical dimension, including the transfer of police equipment from forensic laboratories to assault rifles; an operational dimension, mainly arrest warrants and other forms of collaboration in the fight against transnational crime (terrorism, drug trafficking and illegal migration); and an educational dimension, involving training courses. While liaison officers understand the training and equipment they deliver as development aid, the capacity building they pursue is often aligned with national interests. US officers sponsor anti-terror units, Western European officers support measures against the illegal drug trade and migration, and Chinese officials want to strengthen police protection of expatriates. As a result of these relations, one finds numerous contemporary police ideas and practices in West African police organisations that have travelled there from abroad. To attract international support and funding, the senior police management in Ghana promises to become 'customer-centred'; the Nigerien gendarmerie announces that it will establish new anti-terrorism special forces (see Bayart 2010: 4); rank-and-file police officers justify their practices by referring to the ideas of 'community policing' or 'no broken windows'. 
In this article, we explore how police ideas and practices travel. We do this by focusing on interactions between West African and foreign police officers, since these encounters are what transnational relations consist of in the first place. This paper is based on 15 months of fieldwork in the Ghanaian police and the Nigerien gendarmerie, and two months of joint fieldwork in both Ghana and Niger. We are therefore looking at two particular police organisations, with distinct historical trajectories, structures and procedures (on these organisations see Beek 2014; Göpfert 2014). As researchers 'attached' to diverse police units, we observed everyday practices of policing, conducted narrative and semi-structured interviews with police officers and gendarmes of all ranks, consulted case files and legal documents, and sat in on advanced training courses. This ethnographic approach allows us to revisit questions beyond police research, notably how models travel (diffuse, get carried), what forms these travels take, and how they are adapted. After a brief discussion of previous approaches towards the travel of models and of police models in particular, we will first show how a particular model, namely a particular format of report writing, has travelled from France to Niger through training courses; and how a different model has travelled from the UK to Ghana through organisational entanglements, namely the model of a criminal investigation unit specialised in visa fraud. African police officers have translated these models into their institutional context and thereby made them their own; the reforms did not bring about the changes intended by the sender and their impact on policing as a whole was limited. Second, we explore how - despite the perceived failure of these and other attempts to carry models to West African police organisations - interactions between West African and foreign police entail subtle and yet fundamental exchanges of ideas and policing practices. Most interactions between West African and foreign police officers - many of which do not take place during the official programme but in coffee breaks - are less about lectures and more about telling stories. These stories do not so much convey distinct models but implicit understandings of police and police work - they are about 'policeness' (Hills 2014). Therefore, we suggest that research on the transnationalisation and the travel of ideas, in addition to exploring the journeys of explicit and object-like protocols and policy blueprints, should also consider the stories that emerge in their wake. Stories do not directly cause changes, but they do more than merely reflect them; instead, the potential for change emerges from the turbulences caused by these stories.

\section{Travelling models}

While anthropological interest in state organisations is relatively recent, the question of how ideas and objects circulate has long been one of the central concerns of anthropological research. Social anthropology's move away from the idea of clear-cut and distinct practices and ideas arguably began with diffusionism. Later, unrelated discourses on acculturation, hybridisation and mimesis revisited ideas of cultural exchange and cross-influences. In the 1990s, some anthropologists established the flows and scapes of globalisation as a new field of research (Appadurai 1996: 33). However, these and similar approaches have been criticised for overstretching the metaphors they use and their lack of ethnographic rigor (Amselle 2002: 229).

Current research has largely departed from the macro-perspective that the terms culture and globalisation entail. Instead, as Julia Eckert (2013: 6) convincingly argues, 
transnational relations become visible primarily in everyday encounters. Following this approach, we focus on interactions between actors rather than on those among organisations. Since the mid-2000s, several new analytical concepts have been put forward, each enabling a particular perspective on transnational relations. Criticising the idea of global homogenisation and emphasising local agency, Hans-Peter Hahn and others have used the notion of appropriation, by which globally circulating artefacts and ideas receive specific local meanings (Hahn and Kibora 2008: 88). The downside of this concept, as Verne (2007: 130) and Schneider (2003: 218) point out, is the inherent premise of coherent culture-containers on both ends of the transfer. Others have focused on the main actors in these interactions, namely in terms of 'brokers', respectively 'courtiers' (Bierschenk et al. 2000; Mosse and Lewis 2006) or 'intermediaries' (Merry 2006: 39). The liaison officers in our research could certainly be understood in these terms.

One of the most influential concepts at present is that of 'travelling models', which Behrends et al. (2014) use to describe objectified models - development projects, international policies and legal norms - that are carried from one place to the next (see also Czarniawska and Joerges 1996: 32). Leaving behind notions of global modernisation, rationalisation and unidirectional transfer, the travel metaphor facilitates the exploration of aspects of translation, simultaneity and contingency in transnational relations (Behrends et al. 2014: 6, 12, 21). A central term in this approach is 'translation', mostly drawn from Bruno Latour and Michel Serres (1974). Translation means 'displacement, drift, invention, mediation, the creation of a link that did not exist before' (Latour 1994: 32). It is no longer a matter of original versus copy; it is about who establishes this link - who bridges this 'gap of indeterminacy' (Rottenburg 2003) - and how this changes both the source and target contexts, as well as the object that is being translated. While actors may envision sending their 'untampered' model to other places, the inevitable translation means that it is always appropriated, improved or subverted and all involved are altered (see Behrends et al. 2014: 20). Therefore, travelling models always cause unintended and unexpected effects (Hoinathy and Behrends 2014: 88-9). The police reform projects in Ghana and Niger also had unintended consequences, as we will show in the course of this article.

However, the potential for change seems to be brought about by something else: stories. We found that transnational interactions between individuals are not exclusively about models but to a large extent about stories that travel in the wake of these models. In these exchanges, what is travelling ceases to be a distinct, objectified model and actors no longer perceive it as such. Our findings could still be expressed within the theoretical framework of the travelling models concept. Indeed, storytelling is a form of translation and policeness, arguably, a conglomeration of models. However, we think that our shift in perspective and our ethnographic material warrant a distinct terminology. In short, we want to shift our focus from 'travelling (police) models' towards travelling (police) stories.

\section{Travelling police in the past and present}

In popular perception and early police scholarship alike, the police in West Africa, and in the Global South in general, are regarded as a copy of the model exported from the 
Global North during colonialism. However, since the 1990s, historians have questioned the assumption that the global emergence of police organisations can be appropriately grasped by the concept of comprehensive models, and that its travel was a unidirectional process. Instead, scholars conceptualise transnational relations as a flow of ideas, practices and personnel between the various colonies and England (Anderson and Killingray 1991: 12-13; Sinclair 2006).

This transnational travel of police ideas and practices did not stop with decolonisation but became more global as West African police organisations had more and more international relations beyond their former colonial ties. During the Cold War, the relations depended on the country's political alignment and the development or foreign policy interests of the ideological counterpart elsewhere. And yet, Otwin Marenin's (1986: 513) study of a US-led police reform programme in various African countries attests that the programme had neither positive nor negative effects because policing practices cannot be easily transplanted into African political contexts. However, such police reforms often left some new administrative structures, procedures and run-down equipment behind. According to Thomas Bierschenk (2014), African state organisations consist of such heterogeneous sediments, each resulting from a particular reform project.

Today's proponents and scholars of international police collaboration, police reform and Security Sector Reform (SSR) often seem unaware of these previous - largely unsuccessful - projects. Based on a normative premise, including the wish for 'professionalisation' (Glasman forthcoming), they again conceive of these reforms as one-way model transfers, as 'policy transfers' (see Karstedt 2002). According to Andreas and Nadelman (2008: 251), this homogenisation and cooperation amounts to an 'international crime control industrial complex' on a global scale. Describing the same phenomena, other authors emphasise the problematic implications of these police travels. Referring to Agamben's theory of sovereignty and Foucault's notion of governmentality, they describe the emerging global ideology and apparatus as a 'security-development nexus' that leads to the global employment of counterinsurgency strategies (Buur et al. 2007: 28-32; Fassin 2013: 216). Hönke and Müller (2012: 392) reintroduce the idea of a 'pluri-directional circulation' in transnational security governance.

Regardless of their normative stance, most scholars in the field assume that these transfers of police models have palpable and significant effects on police work in the target countries. Paradoxically, books written for police reform practitioners and consultants cast doubt on that. After lengthy book explanations of how to undertake police reform effectively, the same authors often conclude that all police reforms abroad have hitherto failed to improve police capacity or strengthen accountability (Bayley 2006: 125; Ellison and Pino 2012: 214). Studying a police reform in Nigeria during the 1990s, Hills (2008: 227-8) observes that it had only very local and short-term impact. Even when policies are being implemented, Dixon cautions that ' $[\mathrm{b}]$ eneath the global brand name there has always been a considerable amount of local content' (2007: 178; see also Brogden 2004: 647; Marenin 2009: 349).

Klaus Schlichte (forthcoming) rightly argues that the history of policing in Africa is globally connected. Now we wish to turn to these connections in the present, to look at the travel of a distinct police model, an object-like collection of ideas and techniques: a blueprint for report writing that has been travelling for a long time, mainly through lectures in training courses. 


\section{Travel through training}

One model that has been - and still is - travelling from France to Niger, at least since the late 1980s, is the procès-verbal séparé. It is a specific form of a case file that consists of many small documents instead of a single, unitary one. Procès-verbal is the general term for a case file, characteristic of French legal procedure; such a file sums up a breach of a law and the measures taken in response by police or gendarmes. A procès-verbal is a 'summary of facts', as the gendarmes put it; gendarmes send it to the public prosecutor, who then decides whether and how the suspect should be charged.

The procès-verbal lists every act carried out by the gendarmes: transportation to the scene, observations, measures taken, interrogations, arrests, etc. The gendarmes in Niger collect all this data in one single document, the so-called procès-verbal unique. In France, gendarmes nowadays only write a so-called procès-verbal séparé (separate procès-verbal); they assemble one file that contains separate documents for every single act they carry out (one for transportation to the scene, one for the observations, one for each statement, one for each arrest, etc.) and a recapitulatory report summarising the whole case. The advantage of the latter method is that in the event of a legal or procedural error in one of the separate documents, only this part becomes void by law; in a unitary procès-verbal, an error renders the whole document legally worthless.

In 2011, a French gendarme was sent to Niger to teach the brigade commanders the latest and more efficient form of procès-verbal séparé. ${ }^{1}$ All the gendarmerie's brigade commanders participated in the two-week-long 'recycling courses' (cours de recyclage). The aim was to 'recycle' or retrain them in accordance with the newer standard of separate case files. The participants were the commanders of 70 street-level units in the Nigerien gendarmerie, the brigades territoriales. However, the brigade commanders told us that they had been taught this method some 20 years earlier in their initial coursework and in advanced training courses. But when they returned to their home units as rank-and-file gendarmes, they did not implement it. 'Since our bosses didn't know it, we didn't do it', one brigade commander commented. Their 'bosses', the former generation of brigade commanders, had been taught to write the procès-verbal in keeping with the old standards. This was exactly what the younger gendarmes told us: They had learnt the separate procès-verbal during training, but their commanders wanted them to implement the unitary one. The model was not adapted 20 years ago, and it is not in use now - at least not how the senders intended. How come?

The gendarmes usually explained this quite pragmatically. They did not adapt the new method because an ensemble of several separate reports would consist of far more pages and thus require much more paper and printer ink than needed for the unitary form. And as they lacked sufficient funds from their headquarters, small brigades already had difficulty finding the financial means to purchase paper for the shorter version.

Then they put forward an argument related to style and the wish for coherence (see Göpfert 2013). Senior gendarmes in particular were reluctant to accept the separate procès-verbal because it was much more difficult to produce a coherent narrative in separate, independent reports, they said, than in a single document. In their view, coherence is most important; even the public prosecutor preferred unitary procès-verbal

1 We are withholding or have slightly altered specific dates, places, units, as well as the names of po lice officers and gendarmes we observed and talked to. 
because of its coherence, they explained. The unitary case file eliminates possible contradictions and inconsistencies and makes cases appear rather straightforward.

But there is more to the desire for coherence. Putting all the gendarmes' actions and information into one document or a single narrative makes it much easier to eliminate inconsistencies in their own work, for example, with regards to their arrival time at a crime scene, the time of the different interrogations, and at what time they put the suspect in custody and when they released him - which was always exactly 48 hours after the arrest. As a result, the unitary procès-verbal represents a faultless fiction of the gendarmes' work, and all their actions appear to be in accordance with the law (see Martin 2007: 684).

However, underlying this stylistic argument lies a wish for control. As long as the gendarmes produce coherent facts in a single narrative, their work and particularly how they qualify an offence gains far more clout, as opposed to leaving all this up to the prosecutor. It's a matter of influence, organisational clout and even institutional autonomy. The prosecutor's further actions - to drop the case, to investigate further or to file criminal charges directly - depends primarily on his or her reading of the case file. By means of a coherent narrative, the gendarmes can more easily guide the prosecutor's decisions. As the only ones with detailed information - which the unitary report does not mention - gendarmes are the only ones who are able to aim for an amicable arrangement (arrangement à l'amiable). Such an informal settlement between the disputing parties entails considerable gifts for the gendarmes afterwards.

In very rare cases, however, the gendarmes did compile case reports in the form of separate files. But they only did so in 'delicate' cases, as they called them, when they were being eyed suspiciously. Such cases were particularly tricky when the gendarmes had to arrest an influential public figure like a politician, businessman or relative of a superior officer. Then the gendarmes had their superiors' undivided attention and their primary aim was to protect themselves from interventions and attacks from all sides through an absolutely watertight report. That is to say, the model that has been travelling through workshops for 20 years has indeed arrived - albeit not in the form intended by the French instructors (see Fuest 2014: 58). The gendarmes reinterpreted the format of the separate files as a specific procedural tool for self-protection in cases when the gendarmes' own careers or reputation were on the line. In short, unless their superiors force them to do so or Nigerien solicitors rip every unitary procès-verbal apart, there is little incentive for the gendarmes to change their general writing routine and adapt the model in a way that would better correspond to the French instructors' intentions.

\section{Travel through organisational entanglement}

Training courses are only one way in which police models travel. Another mode of travel is transnational entanglements between organisations on an operational level. In the case of the Ghanaian Border Traffic Fraud Unit, European agencies attempted to bring in a rigid model of Criminal Investigations Department (CID) investigations and to monitor it continually to make it tamper-proof. This unit, a specialised CID in the Ghanaian police, was established at the behest of European embassies and with their financial support in the early 2000s. Before that, the Ghanaian police had 
difficulties pursuing visa fraud. If detected, applicants just reapplied for a visa with a new passport and better-forged documents.

When European officials helped set up the new unit, they demanded that its detectives bring all forgery cases to court. European officials did not think that they were carrying a particular model. In their view, sending nearly all cases to court was part of the basic CID police procedures that had arrived in Ghana already in the 1890s. They also expected the unit to send them case statistics. Ghanaian police officers are used to producing such data, but these are not used to measure police performance. For police reformers and European liaison officers, statistics are part of new public management policies, which have been implemented by European police organisations since the late 1990s (see Shore and Wright 2015). The Europeans' continual supervision was meant to safeguard the CID model against any tampering - or translation - by Ghanaian officers. Without being completely aware of this, European officials introduced new forms of 'evidence making' by using these statistics as an indicator that entailed further actions; they were, in fact, bringing in the latest model of criminal investigations.

The criminal investigations process in the Border Traffic Fraud Unit is straightforward. The consular section of an embassy calls the detectives when an applicant suspected of fraud arrives. Then the detectives come and arrest the suspect on the spot. During one of the arrests we observed, the suspects were a student who had forged a university enrolment certificate to save tuition fees, and a former lawyer who had used forged bank statements to fake a higher income. The detectives asked the suspects to accompany them to CID Headquarters; later, the detectives took their statements in the unit's offices.

In most criminal investigations in Ghana, this is the phase in which the complainants' and the suspects' relatives or friends begin to negotiate in order to settle the case. In Ghana, police officers rarely send cases to court. According to police statistics, $80 \%$ of all criminal cases submitted in Ghana in 2009 were still pending in 2013. Many of these have actually been settled at the police station, which allows the involved parties to end their dispute according to their moral convictions (Beek 2012: 568). Therefore, most cases end at the police station and never go to court. However, the Border Traffic Fraud Unit sends nearly all its cases to court. As the European sponsors use these - in Ghana previously inconsequential - statistics as a tool for measuring the performance and as a basis for future support, the detectives have to adopt and adapt to a rigorous model of criminal investigation.

However, officers and court officials still adapt the model, concerning not what they do at the police station but what they do at court. As all cases are sent forward, the usual negotiations do not take place in the police station as in regular criminal investigations but move from the police station to the court. The detectives charged the suspect with 'possession of forged document', a misdemeanour punishable by a mere fine or up to three years imprisonment. When the judge sat on the two aforementioned cases, the detectives had briefed the suspects about how to plead guilty and even told them the exact sum of money they would need to bring. In the crowded circuit court, the judge angrily admonished the accused for the misdemeanour; but in each case, one of the lawyers sitting in front of the bench jumped up and pleaded with the judge. The lawyer asked the judge to reconsider the case. He brought attention to the accused's humble demeanour, he complained about the byzantine requirements of the visa process and criticised the European embassies for bringing such minor cases 
to court. The bench and the audience nodded approvingly. The former lawyer was cautioned and discharged; the student had to pay a fine of 180 cedi (about $€ 85$ ), to the respectful applause of the audience. The student later lamented that he had no money left for a taxi, as he had to pay his remaining 20 cedi to the detective 'to show appreciation'.

If we look purely at the unit's work, the European model of CID work - both its classic and its new form - appear to have travelled to Ghana without being altered fundamentally. The imported procedures now regulate one stage of the criminal proceedings. However, police officers and court officials have reacted by modifying other stages of the criminal proceedings, thereby thwarting the intended goal of punishing visa fraud more severely. Instead of abolishing the payment of money to settle cases, the obligation to bring all cases to court merely moved this practice to a later stage in the proceedings. Instead of informally settling at the police station, the court becomes a space in which cases are resolved amicably. Although the model of CID work travelled in the form of continual supervision by the senders, the rationalities structuring criminal investigations remain unchanged.

West African police officers are generally very proficient at adapting 'travelling police models' to local rationalities, often in effect completely subverting these models. ${ }^{2}$ The Border Traffic Fraud Unit often does not further their intended mission, but pursues cyber-fraud cases, as these are more challenging and lucrative. When police organisations from abroad organise specialised training courses, West African police officers visit courses unrelated to their specific tasks to earn per diems and collect career-advancing certificates. The transfer of equipment - the logistical dimension of transnational police connections - is often comprehensively subverted to provide additional income for responsible officers. Behind closed doors, West African police officers comment on this just as cynically as foreign liaison officers. In the following, we revisit the carrying of the procès-verbal and CID procedures, to explore the potential for change that emerges with them under the surface of travelling police models.

\section{Transnational interactions as storytelling}

In most publications on the travel of police models, the authors express certain unease about the impact of official modes of travel and to what extent the objects of travel can be described as distinct models. Ellison and O'Reilly (2008: 397) highlight the importance of informal ways of policy transfer. When studying the arrival of human rights standards in the South African police, Julia Hornberger (2003: 93-5) refers to the 'embodiment' and 'personal enactment' of these ideals. Employing a notion of translation, Lars Ostermeier (2014: 249) rejects the idea that 'blueprints of police' are transmitted transnationally. Surprisingly, the professionals carrying police models share the unease concerning a technical understanding of transnational interactions. Foreign liaison police officers stationed in West Africa understand their own activities with a terminology that is akin to the travelling models approach; they say that they bring 'best practices' to African police organisations. However, they often regard implicit teaching methods - like role playing - as more important than lectures, and place special emphasis on informal meetings between foreign trainers and African police officers. While many have

2 Foreign police reformers adapt by becoming private consultants for companies that provide police equipment after retirement. 
become disillusioned about their official projects, they speak hopefully about the subtle impacts of their work: the effects of 'exposure to policing methods' and the 'positive indoctrination' it entails. This reflects police work in general, which is primarily learnt on the job and not in formal training.

As described above, procedures that travel are routinely subverted and, most notably, have only limited impact on the organisation. Still, both scholars and police officers share the notion that something important happens in the wake of travelling models; we could at a glance recognise police officers that had been exposed to foreign police work and these officers all claimed that these experiences had have an immense impact on them. Yet what exactly had happened remained vague and elusive. The emerging practices and beliefs that we are interested in from here on do not come as part of official models, but they are not independent of them either. The emerging practices and beliefs may not be the intended object of training, the delivery of material or of direct collaboration, but they are nonetheless a crucial part of the transnational interactions between police officers from different organisations. When observing these interactions, and when listening to actors talk about them afterwards, it becomes clear that what happens on the ground is storytelling. The Nigerien gendarmes may not have accepted the new model of report writing, or they cobbled together elements of it - in a bricolage between ideal and workable (see Verne 2007: 258-60); but the interaction between the gendarmes and the French instructor was more than a lecture about police procedures. It was a continuous dialogue, in which they exchanged stories, and quite emotionally so.

Not only are stories at the heart of such interactions; they are also the ex post mode of making sense of those interactions. When we asked police officers what they had learned in international training courses or when serving in UN police missions, they nearly always began to tell a story about these events. These stories were not about appropriated procedures; they were an incomplete attempt to give meaning to these events. As such, storytelling is a particular form of translation. Police officers exchange stories to get something across, and later they tell stories about these interactions to make sense of them. By looking at these stories, we can grasp transnationally travelling elements that cannot be conveyed in non-narrative forms, in other words, that cannot be represented as 'models'. Stories are less about what is explicitly stated than about what they imply: we-group formation and questioning the underlying rationalities of police work; police officer-storytellers struggled to make sense of their experiences and two recurring themes or questions arose: who they truly are and what they actually do.

The first theme - who they truly are - came up when officers narrated stories about their relationships with their fellow police officers and those from other countries. A few senior police officers in West Africa declared: 'Policing is the same everywhere and according to international standards'. However, stories were nearly always about differences. Often this was not elaborated, but determined by the storyteller's use of 'we', as it referred mostly to Ghanaian or Nigerien police officers. These narratives were relational self-descriptions and differentiated police officers by nationality. A Ghanaian officer told the story of German police officers who would - in contrast to Ghanaian police - simply sit and wait in their patrol car when on standby; he thereby implicitly characterised the members of his own organisation as less disciplined. By telling stories about the stubborn French, overly strict German, militaristic US American, democratically-minded British and incompetent Pakistani police officers, the storyteller makes sense of his own organisation against the backdrop of others; such 
stories bring to the fore the differences and contradictions in the understandings of police work. However, these stories could also be used to evoke a shared sense of international police or gendarme identity. When both the French instructor and Nigerien brigade commanders said 'we' and 'you', sometimes they did not refer to the national differences but the global community of gendarmes in contrast to soldiers, police or national guards - and above all civilians.

Storytelling enables officers to tackle the second theme of what they actually do in a way that goes beyond mere knowledge transfer. For each step of the criminal investigation process that the French gendarme presented to teach the procès-verbal séparé, he told a story of a particular case he had worked on; each question the gendarmes asked was combined with stories of cases they had worked on. These stories evoked specific techniques of criminal investigations, such as arrests and interrogations; Fludernik (1996: 9) calls this quality of narratives 'experientiality', 'the quasi-mimetic evocation of "real-life experience"'. Evoking this experience allowed officers to convey tacit knowledge, 'embodied knowledge' (Behrends et al. 2014: 2). They were about the fundamental possibilities and impossibilities of police work, for example whether swearing on the Qur'an, a Nigerien marabout's divination or a French dowser's expertise added any value to the truth of criminal investigations. Considering the Nigerien population's deep religiosity, was it admissible for the gendarmes to have victims, witnesses and suspects swear on the Qur'an in order to 'make the truth come out', as the Nigerien gendarmes put it? Was it acceptable to ask the local religious authority for guidance (or his practical help) in specific investigations, for example when a lost object needed to be found or a suspect at large to be arrested? A lot of stories confirmed the efficiency of these instances of 'divine detection'. ${ }^{3}$ At first, the French instructor dismissed these stories and lectured them about forensic science. But what about the few cases in which a dowser was summoned by the French gendarmerie to help during investigations that appeared to have ended in deadlock, he began to muse aloud? In one particular case, a missing person, or rather his dead body, was actually found. Stories about such rather unconventional investigative tools, just like other stories, made up a narrative space perhaps what Behrends et al. (2014: 14) call an 'interstitial space' and Merry (2006: 44) 'shifting subjectivities' - in which both the Nigerien and the French gendarmes questioned, created or stabilised coherent representations of police work, common meanings and definitions, and collective objectives and activities (see Mosse and Lewis 2006: 14). And for both the Nigerien brigade commanders and the French instructor this was a matter of translation, not in the narrow sense of translating knowledge, but as thought of by Martin Fuchs (2009: 26): of going back and forth between the two contexts and experiences to make sense of both (see also Latour 1994: 32).

In this narrative space previously taken for granted experiences and understandings become tangible, recognisable and an object of critical examination. As the case of the French instructor shows, preconceptions held by all participating storytellers, not only West African officers are unsettled; this process is anything but one-directional. ${ }^{4}$ Officers not only narrate other practices in comparison with their own, they reflect on the

3 We borrow this notion from John and Jean Comaroff, developed in their lecture 'Divine detection: crime, policing and the metaphysics of disorder', held by John Comaroff in Mainz, Germany, 6 November 2012.

4 Some German police officers returning from Afghanistan seem to have problems reintegrating into their organisation, as they have grown used to highly improvised and loosely controlled police work (personal communication with Lars Ostermeier). 
differences and evaluate them as well. This becomes palpable when they tell stories about situations in which who they are and what they do becomes muddled. This happens, for instance, during UN missions. The UN police do not recognise national police ranks, and Ghanaian rank-and-file police officers talk enthusiastically about how they removed their (low) rank insignia from their uniforms, how they raised their hands in meetings and how they had been listened to by superiors and that the latter had acknowledged and respected them. But then, they often tell stories about being humiliated and subjected to corporal punishment in their own organisation, for instance how a senior officer had slapped them when they spoke openly on their return from the mission. Other stories are not about hierarchy, but about the joy of using functioning police cars during missions or about the pride they felt of not having to depend on bribes during that time. In the mode of storytelling, police officers can express the experience of contingency or, in other words, the realisation that they could work differently in terms of hierarchies, equipment and relations to civilians. These stories bring with them the sense that they could be different police officers and do other kinds of policing. This experience of contingency that storytelling can provide - so we propose - is at the root of the changes that transnational interactions can bring about. And while storytelling is a form of translation, it may be a more apt concept to explore these contingencies, because it shifts the terminology from incommensurability to potentials.

However, like travelling models, stories do not in themselves change social practices. Police officers employ different ways of narrating such contingent practices. A few storytellers scandalised the practices and rationalities of their organisation and implied that they needed to change; these were often young, low-ranking officers, but whether they managed to change established procedures depended on everyday office politics. In the Ghanaian police, we observed that such officers had brought about significant changes, inventing new procedures, writing new, comprehensive manuals and introducing new leadership styles - not as part of external or internal policy reforms, but as part of changing perceptions of their work. Yet, many more officers have been rejected and felt ignored. The majority of police officers came to terms with or justified West African police work, even when they perceived it as inferior. Their stories sketched non-African police organisations and UN missions as police utopias, but simultaneously suggested that what they had experienced there could not be realised here. By referring to the lack of equipment, low salaries, political influence and civilians' expectations, they represented West African police work as dysfunctional. In their view, current practices were necessary, but an inferior deviation from the original, ideal police models of the Global North. ${ }^{5}$ However, officers also tell stories to question underlying assumptions of the necessity to change and the superiority of policing in the Global North. The detectives in the Ghanaian Border Traffic Fraud Unit - and many of their suspects - told stories in which they juxtaposed the blind bureaucratic requirements of the European embassies with their own approach to negotiate individual cases. In these narrations, these practices could be plausibly represented not as corruption but as discretionary practices that consider the individual and local contexts (see Beek 2012). Instead of emphasising the need for change, officers used these stories to legitimise and strengthen established rationalities of

5 This is in contrast to our notion that police work in West Africa is not fundamentally different (Beek and Göpfert 2013b: 118). 
police work in West Africa. Still, stories of transnational interaction open up a narrative space, in which different practices and beliefs of people from other parts of the world make the known ones recognisable and contingent. By creating these turbulences, such stories inherently entail the potential to bring about change.

\section{Conclusion}

Transnational policing seems contradictory. Police organisations worldwide are nowadays more deeply interconnected than ever before and facilitate a constant travel of 'police models'. There is a widely shared perception of comprehensive changes that these travels bring about. However, when researchers and reform practitioners look at specific programmes, these do not seem to effect any significant changes. Looking at everyday transnational interactions between police officers, we found that such models are always adapted, do not bring about the changes intended by the sender and have only limited overall impact on the organisation, regardless of the specific mode of travel. However, these travels bring about interactions that affect the participants deeply. What happens during and after these transnational interactions is storytelling - providing a narrative space that allows officers to question, subvert or stabilise notions of police identity and police work. In the wake of travelling (police) models, turbulences not changes emerge that may or may not transform the connected organisations.

Shifting the focus from official ties between organisations to storytelling between actors unlocks new sites, media and actor groups for the research of transnational (police) connections. The International Police Association, for instance, organises holiday tours for foreign police officers, thereby creating new storytelling opportunities. Ghanaian detectives watched Chinese cop movies obsessively and Nigerien gendarmes were big fans of the German TV series 'Derrick'; officers worldwide probably learn about policing elsewhere mainly through such stories in popular media. Above all, civilians tell stories about the police they have encountered elsewhere. In West Africa, people tell in bewilderment stories about European police officers who have helped them find their way or enforce the law without considering the wider implications. Since the 1990s, civilian expectations of what police officers should be and do have changed tremendously based on such stories. Such changing expectations or changing beliefs have had an immense impact on policing practices (see Beek and Göpfert 2013a: 483-4); stories not only create the potential for change but also the necessity. Looking beyond the highly metaphorical notion of travel and flows and the highly technical notion of police or security sector reform, we proposed to focus on the stories that actors tell during and after encounters. This may open up a slightly new perspective on the subtle but wide-ranging potential for change that transnational connections can bring about.

\section{Acknowledgements}

The fieldwork was made possible by the German Research Foundation (DFG) and supported by the Laboratoire d'Études et de Recherches Sociologiques sur les Dynamiques Sociales et le Développement Local (LASDEL), Niamey and the Africa's Asian Options (AFRASO) project, funded by the BMBF. For critical comments, we 
are grateful to Carola Lentz, Thomas Bierschenk, Eva Spies, Astrid Erll, our colleagues in Mainz, and particularly to Andrea Behrends for critical and comprehensive feedback on an earlier draft.

\author{
Jan Beek \\ AFRASO \\ Goethe University Frankfurt \\ Senckenberganlage 31 \\ 60325 Frankfurt \\ Germany \\ beek@em.uni frankfurt.de \\ Mirco Göpfert \\ Social and Cultural Anthropology \\ University of Konstanz \\ 78457 Konstanz \\ Germany \\ mirco.goepfert@uni konstanz.de
}

\title{
References
}

Amselle, J. L. 2002. 'Globalization and the future of anthropology', African Affairs 101: 21329.

Anderson, D. and D. Killingray 1991. Consent, coercion and colonial control: policing the empire, 1830 1940, in D. Anderson and D. Killingray (eds.), Policing the empire: government, authority and control, 1830 1940,1 15. Manchester: Manchester University Press.

Andreas, P. and E. Nadelmann 2008. Policing the globe: criminalization and crime control in interna tional relations. New York: Oxford University Press.

Appadurai, A. 1996. Modernity at large: cultural dimensions of globalization. Minneapolis, MN: University of Minnesota Press.

Bayart, J. F. 2010. 'Le piège de la lutte antiterroriste en Afrique de l'Ouest', Societes Politiques Comparees 26: 15.

Bayley, D. H. 2006. Changing the guard: developing democratic police abroad. New York: Oxford University Press.

Beek, J. 2012. "There should be no open doors in the police": criminal investigations in northern Ghana as boundary work', Journal of Modern African Studies 50: 55172.

Beek, J. 2014. Boundary work: the police in Ghana. Dissertation, Johannes Gutenberg University Mainz.

Beek, J. and M. Göpfert 2013a. 'Police violence in West Africa: perpetrators' and ethnographers' dilemmas', Ethnography 14: 477500.

Beek, J. and M. Göpfert 2013b. 'State violence specialists in West Africa', Sociologus 63: 10324.

Behrends, A., S. J. Park and R. Rottenburg 2014. Travelling models: introducing an analytical concept to globalisation studies, in A. Behrends, S. J. Park and R. Rottenburg (eds.), Travelling models in African conflict management: translating technologies of social ordering, 1 40. Leiden: Brill.

Bierschenk, T. 2014. Sedimentation, fragmentation and normative double binds in (West) African public services, in T. Bierschenk and J. P. Olivier de Sardan (eds.), States at work: dynamics of African bureaucracies, 221 45. Leiden: Brill.

Bierschenk, T., J. P. Chauveau and J. P. Olivier de Sardan 2000. Introduction: Les courtiers entre développement et État, in T. Bierschenk, J. P. Olivier de Sardan and J. P. Chauveau (eds.), Courtiers en développement: les villages africains en quête de projets, 5 42. Paris: Karthala.

Brogden, M. 2004. 'Community policing: a panacea from the West', African Affairs 103: 63549.

Buur, L., S. Jensen and F. Stepputat 2007. The security development nexus, in L. Buur, S. Jensen and F. Stepputat (eds.), The security development nexus: expressions of sovereignty and securitization in Southern Africa, 9 33. Uppsala, Cape Town: Nordic Africa Institute, HSRC Press. 
Czarniawska, B. and B. Joerges 1996. Travels of ideas, in B. Czarniawska and G. Sevón (eds.), Translating organizational change, 13 48. Berlin: de Gruyter.

Dixon, B. 2007. 'Globalising the local: a genealogy of sector policing in South Africa', International Relations 21: 16382.

Eckert, J. 2013. Empirie als Kritik: Die Geburt der Ethnologie aus dem Geist der Tragödie. Paper presented at the conference of the German Anthropological Association, Mainz, 3 October.

Ellison, G. and C. O'Reilly 2008. 'From empire to Iraq and the "war on terror": the transplantation and commodification of the (Northern) Irish policing experience', Police Quarterly 11: 395426.

Ellison, G. and N. Pino 2012. Globalization, police reform and development: doing it the Western way? Basingstoke: Palgrave Macmillan.

Fassin, D. 2013. Enforcing order: an ethnography of urban policing. Cambridge: Polity Press.

Fludernik, M. 1996. Towards a 'natural' narratology. London: Routledge.

Fuchs, M. 2009. 'Reaching out; or, nobody exists in one context only: society as translation', Translation Studies 2: 2140.

Fuest, V. 2014. Workshopping owners: policies, procedures and pitfalls of peace building in the non state sector of Liberia, in A. Behrends, S. J. Park and R. Rottenburg (eds.), Travelling models in African conflict management: translating technologies of social ordering, 43 75. Leiden: Brill.

Glasman, J. forthcoming. What is the concept of professionalization good for? An argument from late colonialism, in J. Beek, M. Göpfert, O. Owen and J. Steinberg (eds.), Police in Africa: the street level view. London: Hurst.

Goldsmith, A. and J. Sheptycki 2007. Introduction, in A. Goldsmith and J. Sheptycki (eds.), Crafting transnational policing: police capacity building and global policing reform, 1 29. Oxford: Hart.

Göpfert, M. 2013. 'Bureaucratic aesthetics: report writing in the Nigérien gendarmerie', American Ethnologist 40: 32434.

Göpfert, M. 2014. Enforcing the law, restoring peace: an ethnography of the Nigerien gendarmerie. Dissertation, Johannes Gutenberg University Mainz.

Hahn, H. P. and L. Kibora 2008. 'The domestication of the mobile phone: oral society and new ICT in Burkina Faso', The Journal of Modern African Studies 46: 87109.

Hills, A. 2008. 'The dialectic of police reform in Nigeria', Journal of Modern African Studies 46: 21534.

Hills, A. 2014. 'What is policeness? On being police in Somalia', British Journal of Criminology 54: 76583.

Hönke, J. and M. M. Müller 2012. 'Governing (in)security in a postcolonial world: transnational entanglements and the worldliness of "local” practice’, Security Dialogue 43: 383401.

Hoinathy, R. and A. Behrends 2014. Does rationality travel?: Translations of a World Bank model for fair oil revenue distribution in Chad, in A. Behrends, S. J. Park and R. Rottenburg (eds.), Travel ling models in African conflict management: translating technologies of social ordering, 7691. Leiden: Brill.

Hornberger, J. 2003. “Maman bat papa”. La loi sur la violence domestique à Sophiatown, Johannesburg', Politique Africaine 91: 8399.

Karstedt, S. 2002. 'Durkheim, Tarde and beyond: the global travel of crime policies', Criminology and Criminal Justice 2: 11123.

Latour, B. 1994. 'On technical mediation: philosophy, sociology, genealogy', Common Knowledge 3: 2964.

Marenin, O. 1986. 'United States' aid to African police forces: the experience and impact of the public safety assistance programme', African Affairs 85: 50944.

Marenin, O. 2009. 'The futures of policing African states: police practice and research', An International Journal 10: 34963

Martin, J. 2007. 'A reasonable balance of law and sentiment: social order in democratic Taiwan from the policeman's point of view', Law E Society Review 41: 66598.

Merry, S. E. 2006. 'Transnational human rights and local activism: mapping the middle', American Anthropologist 108: 3851 . 
Mosse, D. and D. Lewis 2006. Theoretical approaches to brokerage and translation in development, in D. Mosse and D. Lewis (eds.), Development brokers and translators: the ethnography of aid and agencies, 1 26. Bloomfield: Kumarian Press.

Ostermeier, L. 2014. 'Processes of transnationalization in international police projects: transfer of knowledge and processes of translation', Kriminologisches Journal 46: 24963.

Rottenburg, R. 2003. Crossing the gaps of indeterminacy, in T. Maranhão and B. Streck (eds.), Translation and ethnography: the anthropological challenge of intercultural understanding, 30 43. Tucson, AZ: University of Arizona Press.

Schlichte, K. forthcoming. Policing Africa: structures and pathways, in J. Beek, M. Göpfert, O. Owen and J. Steinberg (eds.), Police in Africa: the street level view. London: Hurst.

Schneider, A. 2003. 'On "appropriation": a critical reappraisal of the concept and its application in global art practices', Social Anthropology 11: 21529.

Serres, M. 1974. Hermès. Vol. 3: la traduction. Paris: Éditions de Minuit.

Shore, C. and S. Wright 2015. 'Governing by numbers: audit culture, rankings and the new world order', Social Anthropology 23: 228.

Sinclair, G. 2006. At the end of the line: colonial policing and the imperial endgame, 194580. Manchester: Manchester University Press.

Verne, M. 2007. 'Die Rückkehr kultureller Stimmigkeit: Eine Kritik des Aneignungskonzepts nicht nur in Hinblick auf den Verlauf von Mikrokreditprojekten', Sociologus 57: 22765.

\section{Police voyager : le potentiel de changement à la suite des réformes de la police en Afrique de l'Ouest}

Les modèles de police voyagent à travers le monde entier et plusieurs arrivent en forme de réformes de la police en Afrique de Ouest. Sur le terrain, ces connexions transnationales sont composées d'interactions entre les agents de police transportant et recevant de tels modèles. Similaire au voyage de d'autres modèles, les officiers africains adaptent habituellement et subvertissent les réformes officielles. Dans cet article, nous soutenons que le potentiel pour de vaste changement organisationnel est causée, non pas par ces programmes de réforme en tant que tel, mais émerge plutôt par les rencontres que ces voyages apporte. Dans ces rencontres, les agents racontent des histoires qui interpellent ou stabilisent les notions de travail de la police pour ceux qui sont impliqué.

Mots clés transnational, maintien de l'ordre, 'travelling models', narrations, Afrique de l'Ouest 